DOI: $10.31249 / \mathrm{rsm} / 2021.03 .06$

\title{
К. Кумо, И.А. Коргун
}

\section{СТРАТЕГИИ ЭКОНОМИЧЕСКОГО ВОССТАНОВАЕНИЯ ПОСАЕ ПАНАЕМИИ COVID-19: ОПЫT РЕСПУБАИКИ КОРЕЯ И ЯПОНИИ}

Аннотация. Во второй половине XX - начале XXI в. экономическая политика традиционно для эпохи кризисов следовала принциипу установления бюджетных ограничений, снижения расходов и консолидации бюджета. Принципиально иной характер кризиса, спровоцированного пандемией COVID-19, его наложение на глубокие трансформационные сдвиги в национальных экономических системах и мировой экономике в целом, а также геополитические вызовы заставляют правительства искать новые подходы к решению проблем в экономике.

Одной из ключевых тендениий антикризисных мер правительств разных стран стало увеличение бюджетных расходов для поддержки населения и бизнеса, а также разработка планов долгосрочного развития. В настоящей статье исследуются программы по борьбе с пандемией и восстановлению экономик двух восточноазиатских стран - Кореи и Японии - на основании материалов, опубликованных государственными ведомствами и аналитическими иентрами. Отмечается, что характер управления кризисной ситуацией и определение мер для восстановления соответствует стратегическим подходам, иироко применяемьм бизнесом. Рассматриваются вопросы не только характера мер, предпринятых правительствами Кореи и Японии для борьбы с пандемией, но и причинь их успеха, а также задачи экономического развития на посткоронавирусный период.

Ключевые слова: COVID-19; постпандемическое восстановление экономики; экономическая стратегия; Республика Корея; Япония.

Кумо Казухиро - доктор экономических наук, профессор,

директор Центра экономических институтов,

Институт экономических исследований, Университет

Хитоцубаси. Япония, Токио.

Email: kumo@ier.hit-u.ac.jp

Web of Science ResearcherID G-7527-2016

Коргун Ирина Александровна - кандидат экономических наук, старший научный сотрудник, Центр российской стратегии в Азии ИЭ РАН. Россия, Москва.

Email: irinakorgun@gmail.com

Web of Science ResearcherID N-5433-2015/ ORCID ID 0000-0002-1496-4375 
Kumo K., Korgun I.A. Strategies for post-COVID-19 economic recovery: Experiences in Republic of Korea and Japan

Abstract. Traditionally anti-crisis economic policy tended to principles of budgetary restraints, spending cuts and overall budget consolidation. However, the COVID-19 pandemic made governments to re-think the essence of the anti-crisis economic policies. In a highly complex global economic and geopolitical landscape and with ongoing digital transformations in digital economies, governments have to think about specific measures to address these and other challenges like the support of livelihoods and business to be resilient and sustainable.

This paper discusses measures for economic recovery designed by the governments of two East Asian countries - Korea and Japan. The analysis is based on a range of materials published by ministries and analytical centres. The authors argue that the overall approach to emergency management during COVID-19 and the design of short- and long-term support measures were influenced by concepts of corporate strategies. Paper provides answers about the nature of specific measures used by Korea and Japan and explores reasons why they were successful. Authors contribute to the discussion on specific actions that governments had to provide strategic for a vision for the future.

Keywords: COVID-19; post-pandemic economic recovery; strategy; Republic of Korea; Japan.

Kumo Kazuhiro - Dr. \& Professor of Economics, Research Director,

Centre for Economic Institutions, Institute of Economic Research,

Hitotsubashi University. Japan, Tokyo.

Email: kumo@ier.hit-u.ac.jp

Korgun Irina Aleksandrovna - Candidate of Economics,

Senior Research Fellow, The Institute of Economics,

RAS. Russia Moscow.

Email: irinakorgun@gmail.com

Web of Science ResearcherID N-5433-2015

\section{Роль стратегии в постпандемическом восстановмении}

Пандемия Covid-19 создала ряд проблем социального и экономического характера, на которые правительства различных стран вынуждены искать ответы посредством мер экономической политики. Двойственная природа пандемического шока, обусловленного разворачивающимися параллельно резкими изменениями спроса и предложения [Brinca et al 2020], а также высокий уровень неопределенности, который они привносят, заставляет искать подходы, отличные от традиционных мер бюджетных ограничений и сокращения расходов. Уже на данном этапе характерной чертой принятых разными 
правительствами мер стало принятие дополнительных бюджетов для поддержания рынков увеличения рабочих мест, доходов населения, а также укрепления бизнеса.

Однако увеличение расходов без четкой стратегии в долгосрочной перспективе может отрицательно сказаться на последствиях кризиса. В частности, применительно к ситуации в США опасения относительно низкой эффективности дополнительного увеличения выплат населению без мер долгосрочного характера высказывает Л. Саммерс, бывший глава казначейства и советник по экономике правительства Д. Байдена ${ }^{1}$.

На примере двух восточноазиатских экономик - Республики Корея и Японии - рассмотрим необходимость наличия общей стратегии для восстановления экономики и борьбы с последствиями пандемического шока.

Российские ученые в своих работах обращались к особенностям государственной политики в период пандемии, проводимой в данных странах. В частности, А.Н. Федоровский [Федоровский 2020] на примере Южной Кореи отмечает прагматичный, но вместе с тем осторожный подход правительства Мун Чжэ Ина к мерам постпандемического восстановления. Социальные аспекты японской стратегии борьбы с эпидемией и меры денежно-кредитной политики для стимулирования экономики рассматриваются А.В. Беловым [Белов 2020] и Беловым и Тихоцкой [Белов, Тихоцкая 2020]. В данном исследовании предпринята попытка развить темы, затронутые российскими учеными, обсудить подходы к борьбе с кризисными явлениями, а также рассмотреть направления трансформации двух восточноазиатских экономик в ближайшие годы.

Южная Корея и Япония сравнительно успешно смогли преодолеть первую и вторую волны пандемии с минимальными людскими и экономическими потерями. Одна из основных причин этого успеха заключалась в способности правительств этих стран оперативно мобилизовывать имеющиеся ресурсы и определять приоритеты их использования для реализации двух масштабных целей борьбы с чрезвычайной ситуацией и обеспечения условий для последующего роста. Попытаемся развить идею, выдвинутую Фицрой и Спенсер [FitzRoy, Spencer 2020], о необходимости применения двуединого подхода к борьбе с пандемией. Прежде всего имеется в виду, что если меры, направленные на решение первостепенных (чрезвычайных) задач, позволяют смягчить негативные эффекты, то визионерские, т.е. направленные в будущее, меры позволяют создать структурированный путь к устойчивому посткризисному восстановлению.

1. Cм. например: Summers L.H. Trump's \$2,000 Stimulus Checks Are a Big Mistake. Bloomberg, Dec. 27 2020, URL: https://www.bloomberg.com/opinion/articles/2020-12-27/ larry-summers-trump-pelosi-2-000-stimulus-checks-are-a-mistake (accessed: January 21, 2021). 
На основании анализа опыта Японии и Южной Кореи авторы предлагают дополнить двуединый подход за счет включения элементов корпоративных стратегий для борьбы с экономическими последствиями пандемии. Транснациональные корпорации в силу глобальных масштабов своей деятельности часто оказываются в ситуациях, когда на них одновременно воздействуют негативные факторы, имеющие разную природу [Ietto-Gillies, 2012]. Высокая степень неопределенности периода пандемии Covid-19, которая по оценкам специалистов соответствует уровню неопределенности в период кризиса 20082009 гг. и сопоставим по масштабам с Великой депрессией [Baker et al. 2020], a может быть даже превосходит еe [Kissinger 2020], делает актуальным вопрос выработки стратегического ви́дения на национальном уровне. Дополнительными факторами являются усиление экономической конкуренции и борьба за рынки новых цифровых продуктов и товаров в сфере здравоохранения.

Выработка стратегии, согласно М. Портеру, представляет собой «акт сознательного выбора разнообразного инструментария с тем, чтобы обеспечить достижение уникального сочетания ценностных результатов» [Porter 1996]. В условиях продолжающейся пандемии Covid-19 правительства стоят перед необходимостью обеспечить ценностные результаты сразу в нескольких областях - социальной, экономической, технологической и геополитической. В 2020 г. правительства многих стран уже пошли на беспрецедентное расширение мер поддержки, включив такие нетрадиционные механизмы для борьбы с кризисом, как налоговые и регуляторные меры, прямую поддержку отдельных отраслей, выплаты населению и проч. [Ершов 2020]. Но при этом важно стремиться к тому, чтобы меры поддержки также были ориентированы на долгосрочные цели развития, о чем говорится в рекомендациях Организации экономического сотрудничества и развития (ОЭСР) [Coronavirus 2020]. ОЭСР особо выделяет роль долгосрочного стратегического ви́дения в формировании устойчивого экономического восстановления.

Применение стратегического подхода позволит одновременно решать несколько задач. По мнению эксперта в области корпоративной стратегии Йероена Крайдженбринка из Университета Амстердама можно выделить шесть основных задач [Kraaijenbrink 2020]. Во-первых, стратегия направляет действия. В периоды кризисов необходимы своевременные и жесткие ответные меры, т.е. конкретные действия важны как никогда. Правильная стратегия должна помочь людям понять, что необходимо делать, как действовать и реагировать на события. Это верно не только в случае единого и заранее выработанного плана, но и с точки зрения более динамичных действий, которые учитывают изменения среды. Во-вторых, стратегия позволяет адаптировать внутренние условия к изменяющимся внешним условиям. В-третьих, стратегия является единой референтной рамкой для людей. Особенно в периоды кризиса люди имеют склонность искать объединяющие их ценности и 
понятия. В-четвертых, стратегия помогает подготовиться к будущему и, в-пятых, позволяет отличаться, выбирать свой путь. Наконец, верная стратегия обеспечивает стабильность и предсказуемость курса и государственной политики.

\section{Течение пандемии в Южной Корее и Японии}

\section{Южная Корея}

По данным университета Джона Хопкинса, 20 января 2020 г. в Корее был зафиксирован первый случай коронавируса у гражданина, вернувшегося из Китая. Пик первой волны пришелся на середину февраля 2020 г. Тогда общее число ежедневно выявленных случаев превысило 800, но довольно быстро пошло на убыль. Благодаря тому, что ситуация продолжила улучшаться, и в середине апреля число случаев снизилось до менее 10, Южная Корея смогла провести выборы в национальный парламент с рекордной явкой населения.

Вторая волна началась в середине августа 2020 г. и была связана с появлением очага заражения в ночном клубе. Ее удалось взять под контроль в течение месяца. В ноябре Южная Корея вошла в третью волну пандемии. Максимальное количество выявленных за сутки случаев заражения Covid-19 достигло 1237 человек 24 декабря 2020 г., но практически сразу начало снижаться (рис. 1). В этот же период наблюдалось увеличение уровня смертности (в отдельные дни до 20 человек).

Общее число смертей, ассоциированных с вирусом, оценивается корейскими службами в 1316 человек по состоянию на 21 января 2021 г., из них 56,6\% приходится на возрастную категорию свыше 80 лет, еще 37,4\% на возрастную категорию свыше 70 лет, и еще $12 \%$ на людей в возрасте свыше 60 лет [CoronaBoard 2021]. Это указывает на то, что смертельные случаи имели место среди наиболее уязвимых групп населения, а национальная система здравоохранения оказалась готова к тому, чтобы предоставить необходимую помощь большинству заразившихся.

Столкнувшись с реальной угрозой пандемии, когда еще не были выработаны общие подходы к противодействию и сдерживанию распространения, Корее пришлось вводить меры в «ручном» режиме ad hoc. С самого начала правительство избрало тактику, основанную на трех компонентах: тестирование, слежение и изолирование. В частности, в течение двух недель был разработан набор для экспресс-тестирования на Covid-19, позднее заимствованный другими странами - например, Германией и США. Лицензии на тестирование были оперативно выданы частным компаниям и клиникам, что в разы увеличило число ежедневно проводимых тестов (с 3 тыс. в начале февраля до 24 тыс. в феврале-марте). 


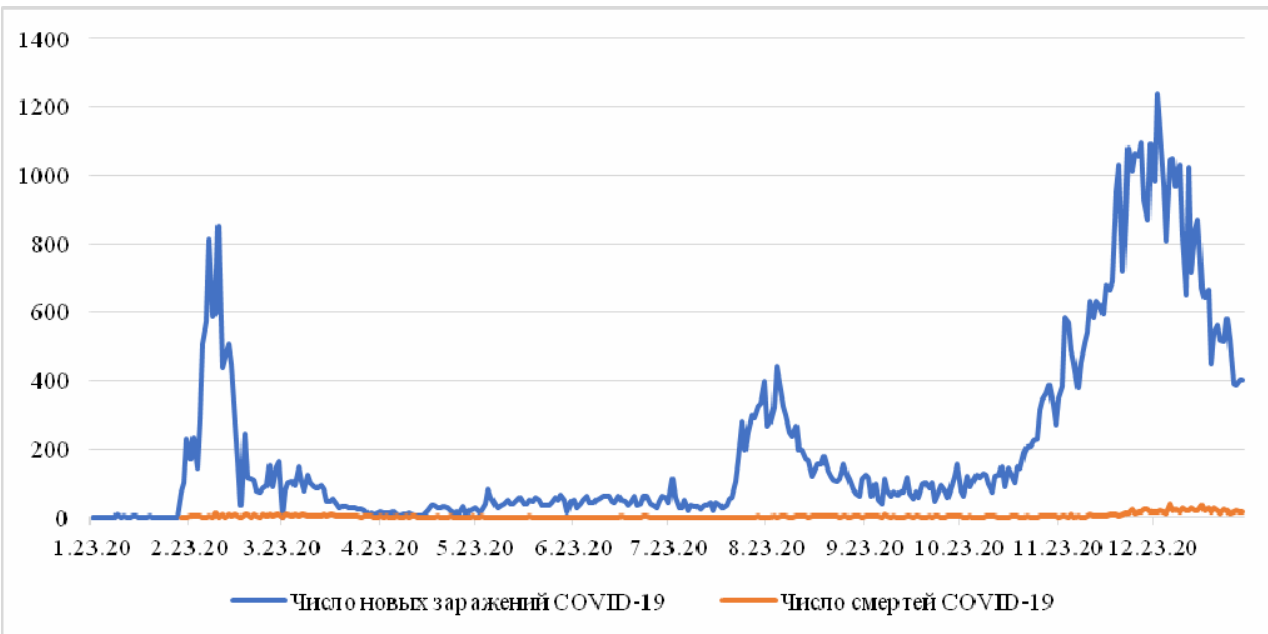

Рис. 1. Число заражений Covid-19 в Корее (23 января 2020-20 января 2021 г.

Источник: сост. по: [Johns Hopkins University 2020]

Использование данных стало еще одной особенностью корейского подхода. Собираемые различными службами данные анализировались с помощью цифровых технологий. Это позволяло отслеживать контакты зараженных и пресекать дальнейшее распространение вируса. Согласно исследованию корейских ученых [Park, Choi, Ko 2020], Южная Корея использовала аналитику больших данных, функционирующую на алгоритмах из проекта по обмену данных, которая называется «платформа сбора данных умных городов». В ней в режиме реального времени анализу подвергались большие массивы данных, что оказалось весьма актуально в условиях быстрого распространения вируса. В результате в Корее возникла такая технологическая инновация, как «умная система управления Covid-19» («Covid-19 smart management system», также известная как «Covid-19 epidemiologic investigation support system»).

Однако широкое использование цифровых технологий и передача данных соответствующим органам имела большой резонанс в связи с утратой конфиденциальности, или «прайвеси», личных данных граждан [Kim 2020]. В СМИ широко тиражировались сюжеты на данную тему. Но при имевших место единичных случаях чрезмерного наблюдения, Корея в целом оказалась подготовленной к подобному мониторингу. Еще в 2015 г. во время вспышки МЕРС (MERS) страна провела Закон «О контроле и предотвращении распространения инфекционных заболеваний» [Infectious Disease Control and Prevention Act], дающий право компетентным органам на обмен данными об инфицированных для предотвращения массового распространения инфекций [You 2020]. Проведенные статистические опросы показали, что $84 \%$ корейцев де-факто 
отказались от части «прайвеси», воспринимая это как необходимую составляющую процесса обеспечения здоровья и безопасности всего общества [You 2020]. Следует заметить, что негативное освещение методов сбора данных об инфицированных в иностранной прессе также не осталось незамеченным: по рекомендации Комиссии по правам человека, правительство ввело ограничения на характер данных об инфицированном человеке, которые могут предаваться огласке [Regular briefing 2020].

Выбранная южнокорейскими властями тактика позволила не вводить в стране массовый локдаун, а ограничиться рекомендациями общего характера по соблюдению дистанционного режима. Жесткие ограничения коснулись только отдельных городов, в частности Тэгу, где первая вспышка была зафиксирована в феврале 2020 г. Нужно отдать должное дисциплинированности общества, которое отреагировало на все рекомендации властей и эпидемиологических служб, неукоснительно соблюдая масочный и дистанционный режимы. Подобное взаимодействие, которое Ю [You 2020] называет государственно-общественное партнерство (public-private cooperation and civic awareness), внесло немалый вклад в успех борьбы с пандемией. Важная роль соблюдения мер социальной дистанции и тщательного мониторинга за распространением вируса в борьбе с эпидемией была подтверждена первичными статистическими исследованиями [Dighe et al 2020].

\section{Япония}

В Японии эпидемия нового коронавируса началась 16 января 2020 г., когда китайский гражданин, проживающий рядом с Токио, получил положительные результаты теста на Covid-19. Немногим более чем за месяц к 21 февраля 2020 г. численность зараженных выросла до 100 человек (рис. 2). С 1 марта 2020 г., правительство закрыло начальные и средние общеобразовательные школы, а 7 апреля 2020 г. ввело чрезвычайное положение в крупных городах: Токио, Осаке, Йокогаме и др. Ограничения были распространены на всю страну уже в середине апреля. Тем не менее правительство Японии, как и правительство Южной Кореи, решило не вводить карантин, несмотря на ужесточение ограничений. Вместо этого оно обратилось к гражданам с призывом воздержаться от «ненужных перемещений» и соблюдать режим самоизоляции. Белов и Тихоцкая [Белов, Тихоцкая 2020] характеризуют подобный подход как либеральный, при этом они отмечают особенность японского социума воспринимать «просьбу» как требование. В силу данной культурной особенности обращение правительства нашло широкий отклик японского населения, которое довольно строго придерживалось всех поведенческих рекомендаций.

Пик первой волны Covid-19 в Японии пришелся на середину апреля 2020 г., но в этом же месяце властям удалось взять ее под контроль. В результате 
чрезвычайное положение и требование самоизоляции было отменено в конце мая 2020 г. Вторая волна коронавируса пришлась на летние месяцы, но уже не сопровождалась столь же масштабными ограничениями, как в первую волну. Как представлено на рисунке 2 , в начале июля число выявленных случаев начало расти, достигнув нового пика к началу августа.

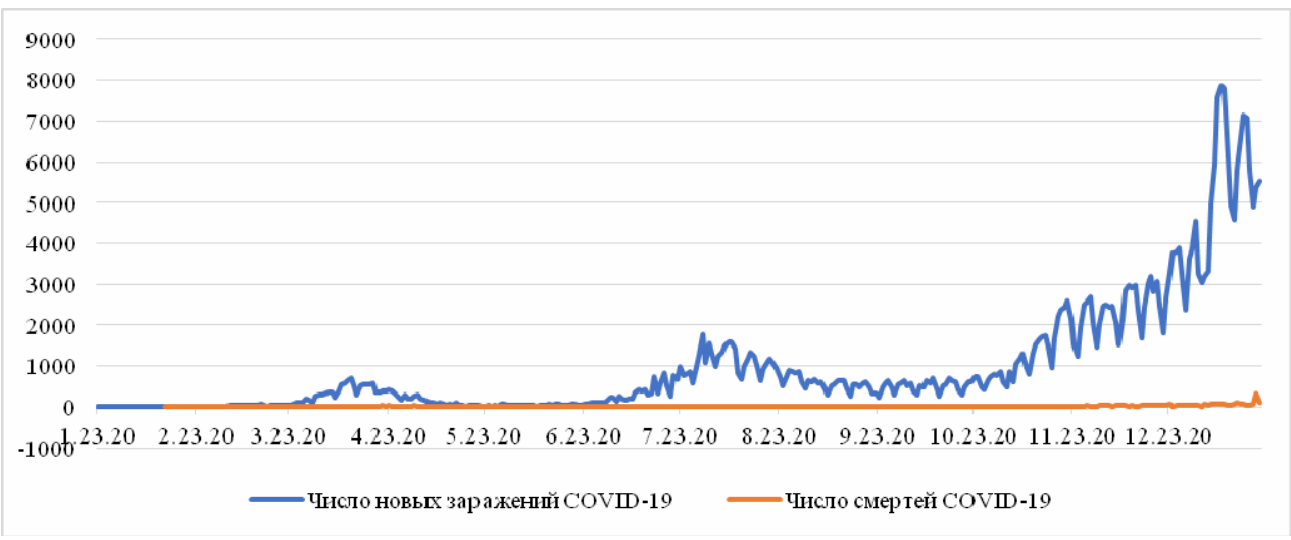

Рис. 2 Число заражений Covid-19 в Японии

(23 января 2020 - 20 января 2021 г.)

Источник: сост. по: [Johns Hopkins University 2020]

Третья волна в Японии пришлась на конец октября 2020 г., и на этот раз последствия были намного серьезнее, чем в двух предыдущих случаях. Количество новых случаев заражения впервые превысило 2000 в конце ноября и достигло 7790 в январе 2021 г. Общее число заразившихся коронавирусом в Японии с начала пандемии достигло 200 тыс. человек (рис. 2). При этом в отличие от многих стран общая численность смертей от коронавируса в Японии остается небольшой. По состоянию на 18 января 2021 г., общее число смертей от Covid-19 составило 4582 случаев. Данная особенность обращает на себя внимание еще и по причине демографической структуры Японии, в которой высока доля населения в возрасте свыше 65 лет: более $30 \%$ японского населения относятся к категории пожилых. Летальные случаи в основном зафиксированы среди людей в возрасте свыше 65 лет (рис. 3). По состоянию на 18 января, среди 4582 смертей $71 \%$ приходится на людей старше 70 лет, при этом на возрастную группу 70-79 лет пришлось 19,7\%, 80-89 и 90+ $34,2 \%$ и $16,8 \%$ смертельных случаев, соответственно. 


\section{РОССИЯ И МИР В ХХІ ВЕКЕ}

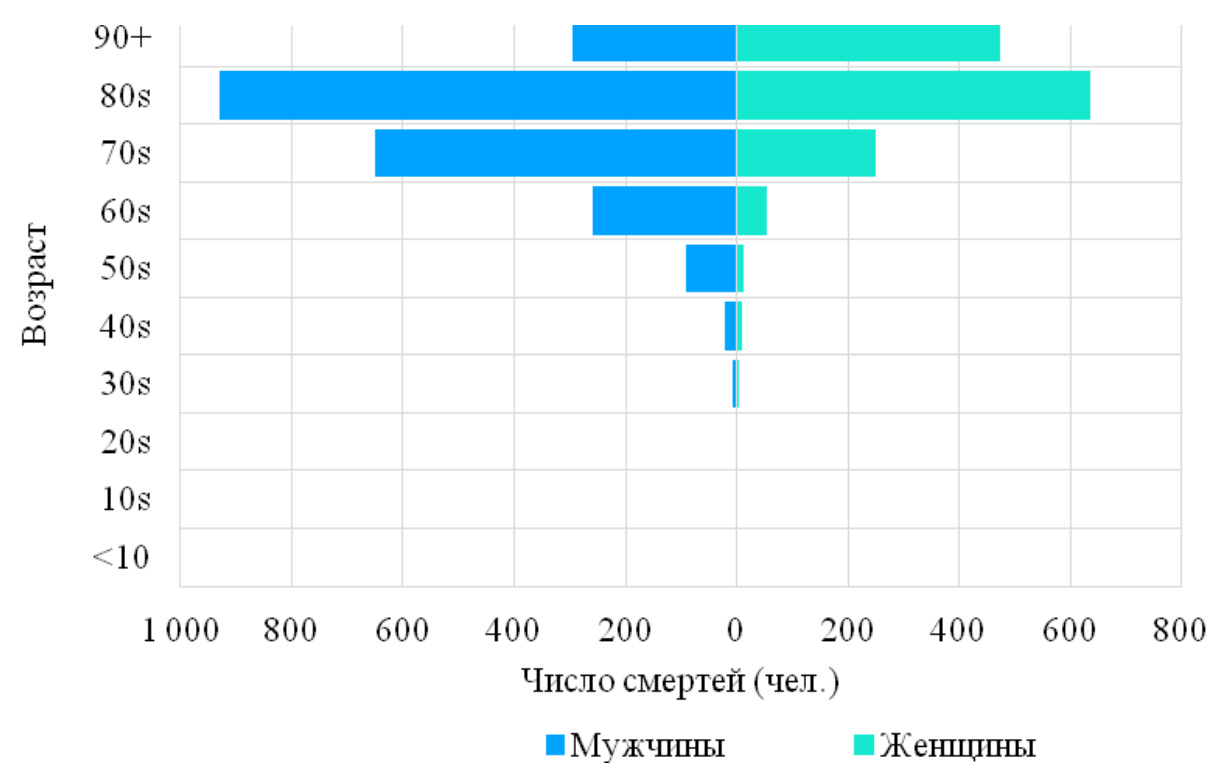

Рис. 3. Половозрастная структура смертности от Covid-19 в Японии (по состоянию на 18 января 2020 г.)

Источник: составлено по: [National Institute of Population and Social Security Research (IPSS) 2021]

По состоянию на 23 января 2021 г., в Японии было зарегистрировано 358527 подтвержденных случаев коронавируса; 288536 случаев выздоровления и 5018 случаев смерти от коронавируса. Однако число проведенных тестов ПЦР составило 6,6 млн, что является небольшим показателем по сравнению с другими странами. Причина заключается в том, что тестирование ПЦР проводится в Японии только при наличии у человека вирусных симптомов или если были контакты с человеком, заболевшим коронавирусом. В остальных случаях тестирование не является обязательным [Nishiura et al. 2020]. Таким образом, в отличие от Южной Кореи, Япония не сосредоточилась на тестировании для сдерживания распространения инфекции, а сделала ставку на качество системы здравоохранения. Интересно заметить, что даже в таких условиях (ограниченное тестирование и отсутствие локдауна) численность смертей от Covid-19 остается крайне низкой, в том числе относительно количества зараженных [Shimizu, Negita 2020].

В целом, Южная Корея и Япония с относительно небольшими потерями прошли первую и вторую волны пандемии. Несмотря на то, что третья волна 
в них оказалась более сильной, чем предыдущие, количество смертельных случаев и размеры экономических потерь были сравнительно ниже, чем в других странах. По оценкам Института нового экономического мышления, Корея и Япония не перешагнули тот порог, когда ради спасения жизней пришлось «пожертвовать экономикой» [Wolf 2020]. При этом объемы поддержки, которые предоставили их правительства, оказались одними из самых масштабных (с учетом размеров экономик).

\section{Экономическая ситуация, подАержка экономики и стратегия восстановиения}

\section{Южная Корея}

На рисунке 4 представлены основные экономические показатели Кореи за первые три квартала 2020 г. Наибольшее сокращение ВВП пришлось на второй квартал и составило (-)3,2\% в годовом измерении. Заметим, что замедление экономики наметилось уже в первом квартале, когда спад составил (-) $1,3 \%$, но в третьем квартале показатели роста ВВП вернулись к положительным значениям и составили $2,1 \%$ (рис. 4). По предварительным оценкам Банка Кореи, рост в четвертом квартале 2020 г. также был положительным $1,1 \%$. Несмотря на то, что по итогам года ВВП сократился на $1,4 \%$ по сравнению с 2019 г., положительная динамика в третьем и четвертом кварталах 2020 г. позволила минимизировать потери.

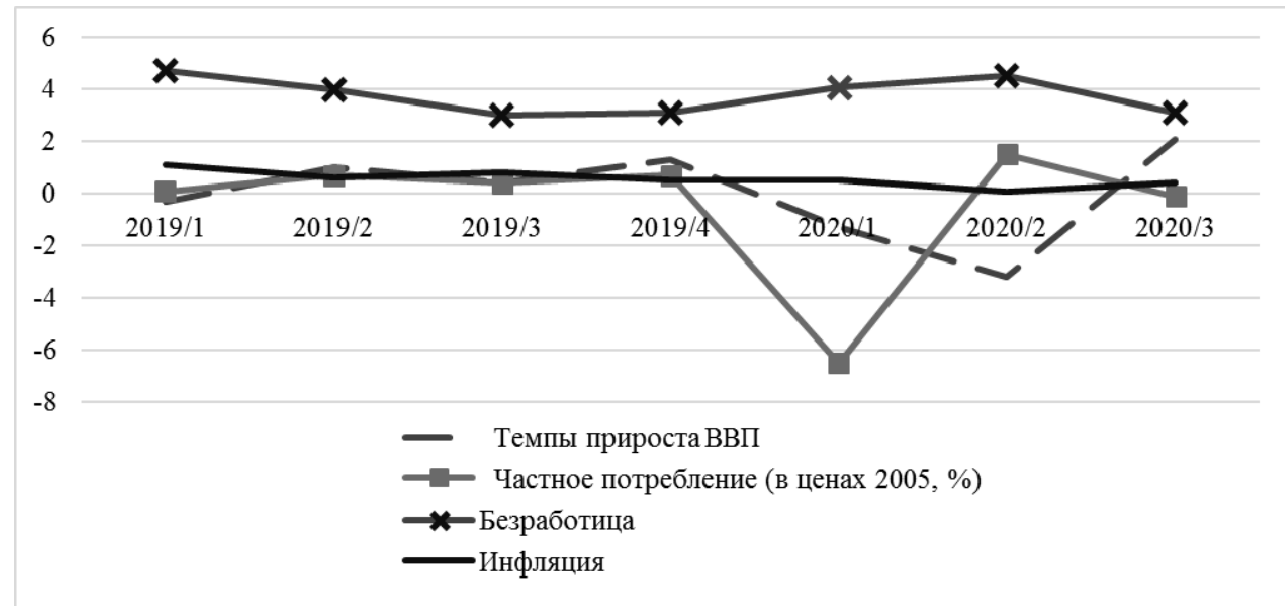

Рис. 4. Прирост ВВП Кореи (1 квартал 2019 - 3 квартап 2020 г.)

Источник: сост. по: [Bank of Korea 2020] 


\section{РОССИЯ И МИР В ХХІ ВЕКЕ}

Улучшение экономической ситуации было зафиксировано также другими показателями. Например, по данным Банка Кореи, индекс потребительских настроений на пике коронавируса снизился до 70,8, однако к ноябрю практически вернулся на докризисный уровень - 97,8 [Bank of Korea 2020]. В ожиданиях бизнеса также произошли существенные изменения к лучшему: соответствующий индекс вырос с 51 в апреле до 78 в ноябре. Позитивные ожидания были зафиксированы в различных отраслях экономики, а также среди компаний, ориентированных как на внутренний, так и на внешний спрос.

В течение 2020 г. уровень безработицы оставался стабильным и в целом ниже показателя февраля 2019 г., когда на рынке труда наблюдалось увеличение числа безработных (рис. 4). Инфляционное давление оставалось низким - менее $1 \%$, при этом в октябре имели место дефляционные тенденции. Доходы домохозяйств в Корее сократились на 1,3\% в первом квартале, но благодаря государственной поддержке в форме прямых выплат во втором квартале 2020 г. доходы выросли на 5,6\%. Однако рост доходов сопровождался ростом уровня задолженности населения. В частности, по данным Банка Кореи, возросло кредитование как по кредитным картам (в форме невыплаченных долгов), так и в виде целевых банковских кредитов. Темпы увеличения долговых обязательств населения в третьем квартале 2020 г. приблизились к уровню конца 2017 г., когда наблюдалось ускоренное увеличение потребительской задолженности [Bank of Korea 2020].

Повышение долговой нагрузки на население в среднесрочной перспективе может привести к тому, что потребители и малый бизнес не смогут обслуживать свои обязательства и будут вынуждены сократить потребление. Соответственно это будет влиять на уровень общего спроса в экономике и потребительские расходы в 2021 и 2022 гг. Комиссия по финансовым услугам Кореи уже в июле 2020 г. указывала на то, что задолженность малого и среднего бизнеса достигла рекордной величины 83,4 млрд долл., что в условиях пандемии создает серьезный риск для экономики [Building 2020].

Пакет мер поддержки для борьбы с последствиями Covid-19, принятый корейским правительством, можно охарактеризовать как масштабный и широкий по видам использованных инструментов; в него вошли фискальные, финансовые, монетарные, налоговые и прямые выплаты (для поддержания доходов). ОЭСР оценивает общий пакет мер в 14,4\% ВВП, включая поддержку финансовых рынков в марте 2020 г. и кредитные гарантии пострадавшим компаниям. При этом уже на ранних этапах в действиях корейских властей прослеживалось стремление увязать меры поддержки с общими целями развития страны, которые включают такие фундаментальные проблемы, как борьба с неравенством и развитие перспективных технологически емких отраслей для обеспечения роста в средне- и долгосрочной перспективе. Впоследствии эти устремления были конкретизированы и оформлены в полномасштабную стратегию восстановления экономики. 
Рассмотрим более подробно экономические меры корейского правительства с точки зрения таких характеристик, как оперативность предоставления поддержки, широта набора использованных инструментов, изменение внешней среды и ориентация на рост.

\section{Эффективность и оперативность действий}

В контексте пандемии Covid-19 эффективность поддержки означает, что были минимизированы временные затраты на обсуждение необходимости поддержки. Корейский парламент начал обсуждать экономические инструменты в феврале параллельно с развитием первой волны коронавируса. Когда большинство стран еще не столкнулось с пандемией и в мире не было дискуссии о том, какие меры экономического характера могут быть задействованы, Корея определила необходимость срочных мер для поддержки населения и бизнеса. К началу марта, т.е. в течение трех недель после обнаружения первого случая Covid-19, были выделены средства для поддержки туристической отрасли, экспортно ориентированных предприятий и пострадавших семей. В марте Национальная ассамблея утвердила пакет мер на сумму сначала в 11,7 трлн корейских вон и далее на сумму в 100 трлн вон (расширенную до 200 трлн вон) для кредитных гарантий и дополнительных кредитов бизнесу и физическим лицам, стабилизационный фонд для фондовых рынков, программы по сохранению занятости. По мере развития ситуации Национальная ассамблея несколько раз утверждала дополнительное финансирование экономических программ в апреле, июне, июле и сентябре.

\section{Разнообразие схем поддержки}

Как и во многих странах, одни из основных мер поддержки в Корее были направлены на поддержание доходов населения, занятости и помощь бизнесу в форме облегчения доступа к кредитным ресурсам и отсрочки по уплате налогов. Отличие корейского подхода составило наличие таргетированных схем поддержки для более узких групп занятых [4 th Emergency Support Package 2020]. Например, начиная с октября корейское правительство разработало схемы для фрилансеров, водителей такси или людей, которые являются основными кормильцами семьи и имеют членов семьи на иждивении. Объем выплат по данным схемам составил от 1 млн корейских вон до 1,5 млн вон (что эквивалентно 1-1,3 тыс. долл. США) на период до трех месяцев. Несмотря на краткосрочный характер схем, предполагалось их продление, если мониторинг выявит необходимость этого [Covid-19 targeted emergency measures 2020].

Как и в случае борьбы с эпидемией, корейское правительство тщательно следит за положением особо ущемленных групп населения, постоянно выявляет возникающие нужды и принимает своевременные меры помощи. Тем 
самым правительство стремится сделать выход из кризиса социально ориентированным. Помощь не ограничивается исключительно денежными выплатами, разрабатываются программы профессиональной переподготовки, направленные на адаптацию населения к работе в условиях цифровой экономики [Professional skills 2020]. Данные программы сфокусированы на том, чтобы готовить кадры для новых стратегических отраслей, улучшить навыки работы с искусственным интеллектом, цифровыми и мобильными технологиями. В целом усилия по введению широких программ помощи населению указывают на стремление обеспечить инклюзивное восстановление и несмотря на сложные условия продолжать решение проблемы социального неравенства, обострившейся в стране в последнее десятилетие.

Принятие во внимание изменение условий внешней среды

Стратегический характер мер по преодолению последствий Covid-19 oпределяется тем, что, разрабатывая программу восстановления, корейское правительство принимало во внимание не только процессы, происходящие внутри страны, но и в мировой экономике. В мае была представлена «матрица», отражающая основные риски для экспортно ориентированной корейской экономики и тактические решения по их нейтрализации (табл. 1). Данная матрица резюмирует произошедшие изменения в области социальных взаимодействий, растущую значимость здравоохранения для национальной безопасности и продолжающие развиваться протекционистские тенденции. Соответственно, чтобы нейтрализовать или, по крайней мере, снизить негативное воздействие данных рисков, Корея планирует разрабатывать и производить больше медицинских товаров и продвигать их на внешних рынках, развивать региональные цепочки добавленной стоимости для диверсификации поставок, содействовать многостороннему подходу в торговле. Несмотря на простоту, данная матрица задает единые и понятные цели и позволяет лучше координировать работу различных органов и министерств для их достижения.

Таблица 1

Изменение общей ситуации / хозяйственной среды после пандемии

\begin{tabular}{|l|l|l|l|}
\hline \multicolumn{1}{|c|}{ Сфера } & \multicolumn{1}{|c|}{ До } & \multicolumn{1}{c|}{ После } & \multicolumn{1}{c|}{ Меры } \\
\hline Здравоохранение & Периодические & Частые вирусные & Продвижение корей- \\
& вирусные заболевания & заболевания & боваров по борь- \\
& & & среронств персонусом и \\
& & & защиты, \\
& & & усиление устойчиво- \\
& & & сти промышленности \\
& & & всловиях пандемий \\
\hline
\end{tabular}




\begin{tabular}{|c|c|c|c|}
\hline Сфера & До & После & Меры \\
\hline & Глобальные закупки & Локальные закупки & $\begin{array}{l}\text { Трансформация цепо- } \\
\text { чек поставок, созда- } \\
\text { ние новых производ- } \\
\text { ственных центров }\end{array}$ \\
\hline $\begin{array}{l}\text { Экономическая } \\
\text { среда }\end{array}$ & $\begin{array}{l}\text { Традиционные формы } \\
\text { хозяйственной } \\
\text { деятельности. } \\
\text { Рост спроса на нефть }\end{array}$ & $\begin{array}{l}\text { Расширение элект- } \\
\text { ронной коммерции } \\
\text { и цифровой эконо- } \\
\text { мики в целом; } \\
\text { телемедицина. } \\
\text { Снижение спроса } \\
\text { на нефть }\end{array}$ & $\begin{array}{l}\text { Создание и развитие } \\
\text { отраслей цифровой } \\
\text { экономики. } \\
\text { Реструктуризация } \\
\text { промышленности } \\
\text { с учетом энергосбере- } \\
\text { гающих технологий }\end{array}$ \\
\hline $\begin{array}{l}\text { Управление } \\
\text { компаниями }\end{array}$ & $\begin{array}{l}\text { Сокращение } \\
\text { издержек, } \\
\text { эффективность }\end{array}$ & $\begin{array}{l}\text { Обеспечение произ- } \\
\text { водственных запа- } \\
\text { сов, устойчивость }\end{array}$ & $\begin{array}{l}\text { Повышение } \\
\text { устойчивости } \\
\text { компаний }\end{array}$ \\
\hline $\begin{array}{l}\text { Социальные } \\
\text { ценности }\end{array}$ & $\begin{array}{l}\text { Индивидуализм, } \\
\text { эффективность }\end{array}$ & $\begin{array}{l}\text { Солидарность, } \\
\text { сотрудничество }\end{array}$ & $\begin{array}{l}\text { Сотрудничество на } \\
\text { разных уровнях, в том } \\
\text { числе в бизнесе }\end{array}$ \\
\hline $\begin{array}{l}\text { Внешняя } \\
\text { торговля }\end{array}$ & $\begin{array}{l}\text { Свобода торговли, } \\
\text { либерализм }\end{array}$ & Протекционизм & $\begin{array}{l}\text { Поддержание идей } \\
\text { международного } \\
\text { сотрудничества }\end{array}$ \\
\hline
\end{tabular}

Источник: сост. по: [Government 24]

\section{Ориентированность на рост}

Программа восстановления Кореи в высшей степени ориентирована на то, чтобы использовать кризис для перестройки и заложения фундамента для роста в средне- и долгосрочном периоде. Часть фондов для борьбы с пандемическими шоками должна пойти на НИОКР - развитие цифровых технологий, цифровых платформ, искусственного интеллекта. Всего было выделено десять направлений, представленных в таблице 2, по которым будет вестись работа. Данные меры способны обеспечить ускоренную цифровизацию за счет внедрения цифровых технологий и искусственного интеллекта в повседневную жизнь людей. Особое внимание планируется уделять телемедицине, коммерциализации автомобилей с электроприводом, технологиям $5 \mathrm{G}$ и обновлению цифровой инфраструктуры. Данная программа получила название «Korea-style New Deal».

Аллюзия к рузвельтовскому «новому курсу» в названии программы по восстановлению экономики предполагает наличие социальной составляющей и ориентацию на стабильность в новых условиях. Корейское правительство будет стремиться к тому, чтобы создавать новые рабочие места и перенаправлять высвобождающиеся в традиционных секторах трудовые ресурсы в новые отрасли. Особый акцент на цифровизацию связан, в том числе, и с причинами демографического характера - старением населения и падением рождаемости. 
Меры экономического стимуяирования

\begin{tabular}{|c|c|c|}
\hline \multirow[t]{3}{*}{$\begin{array}{c}\text { Создание } \\
\text { цифровой } \\
\text { инфраструктуры }\end{array}$} & $\begin{array}{l}\text { Система для сбора } \\
\text { и использования данных }\end{array}$ & $\begin{array}{l}\text { Усиление инфраструктуры генерирования } \\
\text { данных. } \\
\text { Внедрение технологий по сбору данных } \\
\text { в такие отрасли, как финансы, медицина, } \\
\text { государственные услуги, дорожную } \\
\text { службу }\end{array}$ \\
\hline & $\begin{array}{l}\text { Обновление систем } \\
\text { посредством внедрения } \\
\text { сетей } 5 \mathrm{G}\end{array}$ & $\begin{array}{l}\text { Создание инфраструктуры } 5 \text { G. } \\
\text { Развитие отраслей совместимых с } 5 \text { G+ }\end{array}$ \\
\hline & $\begin{array}{l}\text { Расширение инфраструк- } \\
\text { туры искусственного ин- } \\
\text { теллекта и ее ввод в эко- } \\
\text { номику }\end{array}$ & $\begin{array}{l}\text { Расширение отраслей с использованием } \\
\text { искусственного интеллекта. } \\
\text { Внедрение технологий искусственного } \\
\text { интеллекта во все отрасли экономики }\end{array}$ \\
\hline $\begin{array}{l}\text { Формирование } \\
\text { цифровых } \\
\text { отраслей }\end{array}$ & \multicolumn{2}{|c|}{$\begin{array}{l}\text { Создание основ для роста цифровых и онлайн-услуг, в особенности } \\
\text { образовательных, велнес, телемедицины. } \\
\text { Усиление кибербезопасности и безопасности облачных хранилищ } \\
\text { данных }\end{array}$} \\
\hline $\begin{array}{c}\text { Цифровизация } \\
\text { социальной } \\
\text { инфраструктуры }\end{array}$ & \multicolumn{2}{|c|}{$\begin{array}{l}\text { Цифровизация для нейтрализации негативного эффекта старения } \\
\text { населения. } \\
\text { Формирование системы цифровой логистики }\end{array}$} \\
\hline
\end{tabular}

Источник: сост. по: [박시현 2020]

\section{Япония}

В своем ежемесячном экономическом отчете за март 2020 г. японское правительство заявило, что «в настоящее время экономика находится под серьезным давлением из-за воздействия новой коронавирусной инфекции» и пересмотрело экономические оценки в сторону ухудшения ситуации. Из официальных коммуникаций о состоянии экономики впервые за более чем шесть лет была удалена фраза «путь постепенного восстановления», которая неизменно использовалась, начиная с июля 2013 г. Отчет правительства от 23 апреля 2020 г. подтвердил опасения относительно ухудшения экономической ситуации, в результате чего было заявлено о том, что «состояние экономики быстро ухудшается в связи с воздействием новой коронавирусной инфекции. Ситуация остается крайне тяжелой». В отчете впервые с мая 2009 г. использовано слово «ухудшение», что в культурном контексте означает серьезную озабоченность властей. 


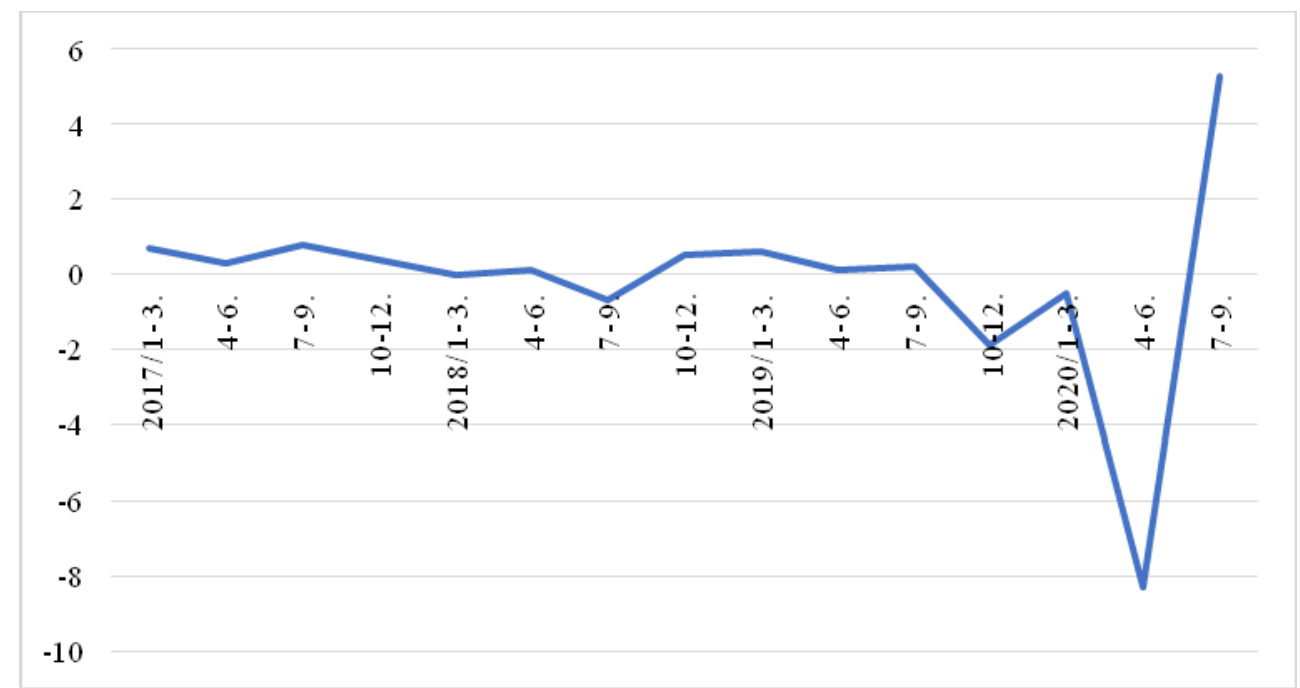

Рис. 5. Темы прироста ВВП (1 квартал 2017 - 3 квартал 2020 г.)

Источник: сост. по: [Cabinet Office of Japan 2020]

Действительно, японский ВВП за период с апреля по июнь снизился на $7,9 \%$ по сравнению с предыдущим кварталом, или упал на $28,1 \%$ в годовом исчислении (рис. 5). Министерство внутренних дел и коммуникаций (МВДК) 30 июня 2020 г. объявило, что уровень безработицы в мае составил $2,9 \%$, что является самым высоким показателем по сравнению с уровнем безработицы в мае 2017 г. (рис. 6). Другие экономические показатели состояния экономики также зафиксировали рекордное падение уровня экономики. Так, число новых вакансий в апреле 2020 г. сократилось на $22,9 \%$ по сравнению с предыдущим месяцем, что является самым большим снижением за всю историю наблюдений. Продажи крупных универмагов снизились на $72,8 \%$ по сравнению с аналогичным периодом прошлого года, что также является самым большим падением за всю историю статистических наблюдений. В мае 2020 г. экспорт сократился на $28,3 \%$ по сравнению с аналогичным периодом предыдущего года. Это является самым большим падением с сентября 2009 г. Таким образом пандемия вызвала масштабное сокращение японской экономики. Однако к концу 2020 г. негативные тенденции стали замедляться. 


\section{РОССИЯ И МИР В ХХІ ВЕКЕ}

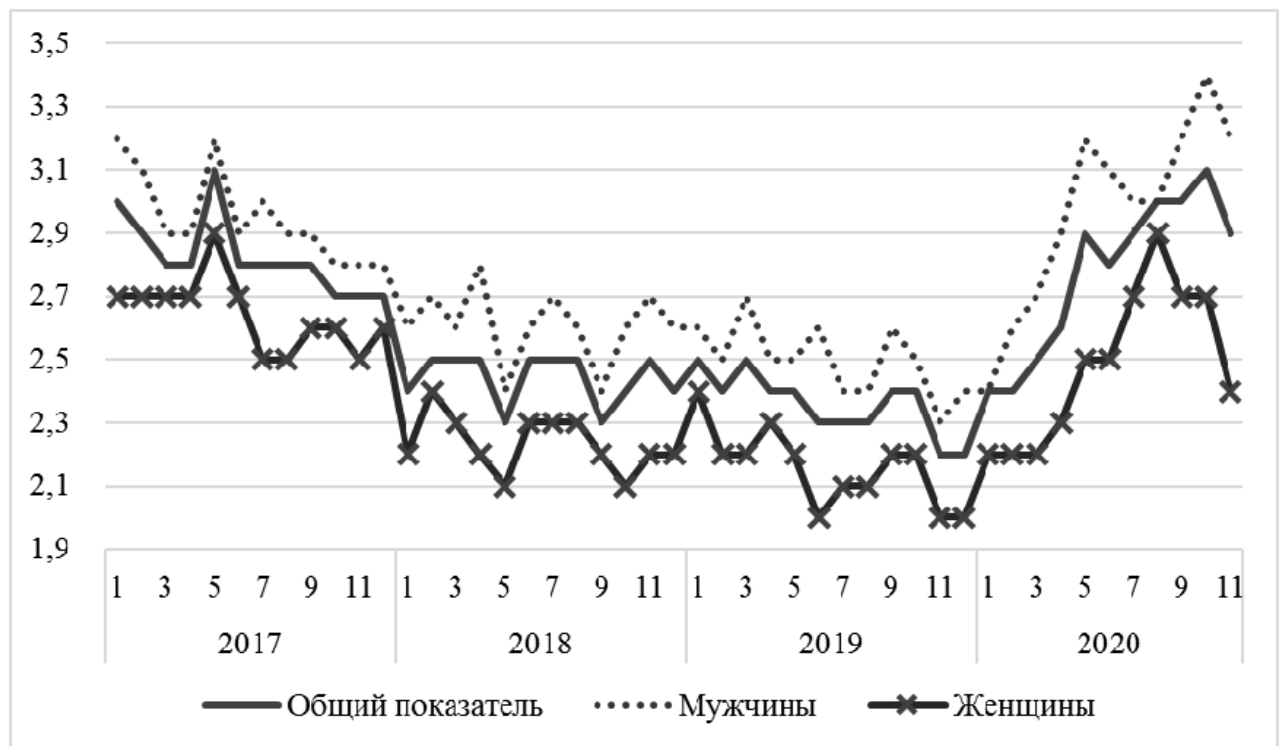

Рис. 6. Аинамика уровня безработицы в Японии (январь 2017 - ноябрь 2020 г.)

Источник: сост. по: [Cabinet Office of Japan 2020]

Поддержка на начальных этапах

Для борьбы с экономическими последствиями пандемии японское правительство приняло две поправки к бюджету. Первый дополнительный бюджет был принят 30 апреля 2020 г., в соответствии с ним, общая сумма расходов составляет 26 трлн иен (250 млрд долл.). В первую поправку были заложены единовременные выплаты в размере 100 тыс. иен для всех граждан. Данная мера была направлена прежде всего на то, чтобы поддержать доходы домохозяйств и, как значится в государственном пресс-релизе, способствовать «национальной солидарности против коронавируса». Также правительство ввело систему субсидирования с помощью «скидочных» купонов на расходы потребителей на питание вне дома и на проезд, а также отсрочки налоговых платежей и выплат по социальному страхованию.

Второй дополнительный бюджет был принят 12 июня 2020 г. За него проголосовали почти все оппозиционные партии, кроме либеральнодемократической. Общие расходы составили 32 трлн иен (308 млрд долл.), что является самой большой суммой дополнительного бюджета, принятого правительством Японии, превысив размер дополнительного бюджета, одобренного после кризиса 2008 г. Одной из наиболее значимых статей расхода 
в структуре поддержки являются меры экстренной помощи малому и среднему бизнесу (МСБ). На поддержку могут рассчитывать те предприятия, ежемесячная выручка которых сократилась более чем на $50 \%$ в любой месяц 2020 г. по сравнению с аналогичным месяцем предыдущего 2019 г.

Стоит заметить, что в ходе распределения помощи были выявлены многочисленные случаи мошенничества с мерами поддержки: люди, не являющиеся предпринимателями, выдавали себя за владельцев бизнеса и благополучно получали помощь. Однако в то же время было очевидно, что поддержка домашних хозяйств критически повлияла на объем доходов домашних хозяйств, которые резко увеличились в период с мая по июль 2020 г. (рис. 7). Более подробная информация о мерах государственной поддержки в Японии приведена в таблице 3.

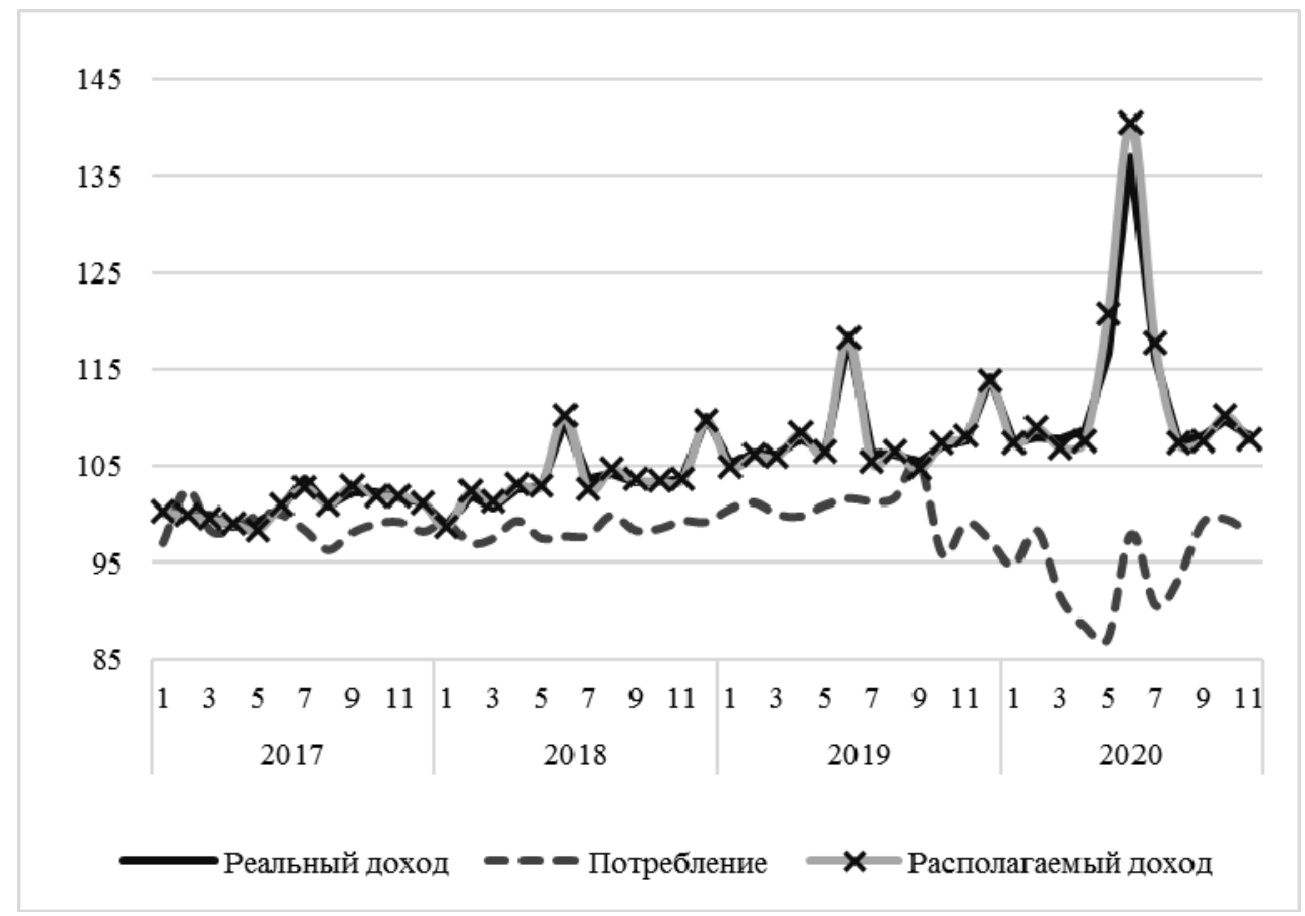

Рис. 7. Аинамика индексов уровня доходов и потребления*

*Средний уровень за 2015 г. взят за 100\%

Источник: сост. по: [Cabinet Office of Japan 2020] 


\section{РОССИЯ И МИР В ХХІ ВЕКЕ}

Таблица 3

Меры государственной экономической подАержки в Японии

\begin{tabular}{|c|c|}
\hline Экстренная помощь для домохозяйств & $\begin{array}{c}\text { Экстренная помощь для малого и среднего } \\
\text { бизнеса }\end{array}$ \\
\hline $\begin{array}{l}\text { Новые наличные платежи для всех жителей } \\
\text { Японии. } \\
\text { Наличный платеж всем жстелям Японии с } \\
\text { целью укрепления национальной солидарно- } \\
\text { сти против Соvid-19. } \\
\text { Приблизительно 12,9 трлн иен: } \\
100 \text { тьс. иен на каждого жителя Японии, } \\
\text { свободнье от обложения налогом. } \\
\text { Форма заявки отправляется по электронной } \\
\text { почте. Онлайн-заявка доступна пользовате- } \\
\text { лям карть «Мой номер» }\end{array}$ & $\begin{array}{l}\text { Новые наличные платежи для малых и средних } \\
\text { предприятий, а также для индивидуальных } \\
\text { предпринимателей. } \\
\text { Приблизительно 2,3 трлн иен. } \\
\text { Наличные платежи различным предприятиям } \\
\text { (включая некоммерческие организации, предпри- } \\
\text { ятия здравоохранения), которые можно ис- } \\
\text { пользовать в более иироком масштабе. } \\
2 \text { млн иен для организаиий и } 1 \text { млн иен для инди- } \\
\text { видуальных предпринимателей, чей доход упал } \\
\text { более, чем на 50\% в любой из месяцев } 2020 \text { г. } \\
\text { Финансовые меры (помощь в управлении де- } \\
\text { нежными средствами). } \\
\text { Беспрочентньй беззалоговый кредит (с от- } \\
\text { срочкой погашения основной суммы долга до } \\
5 \text { лет через частные финансовые учреждения, } \\
\text { кроме государственных финансовых учрежде- } \\
\text { ний (например, JFС). } \\
\text { Рефинансирование непогашенной ссуды до бес- } \\
\text { проиентной ссуды }\end{array}$ \\
\hline $\begin{array}{l}\text { Дополнительное пособие на ребенка в раз- } \\
\text { мере } 10 \text { тыс. иен на каждого ребенка. } \\
\text { Сверх регулярного месячного пособия на ре- } \\
\text { бенка в размере } 10 \text { тыс.иен на ребенка, сво- } \\
\text { бодное от обложения налогом. } \\
\text { Экстренное микрокредитование неблагопо- } \\
\text { лучных семей. } \\
\text { Максимальный кредит составляет } 200 \text { тыс. } \\
\text { иен (без процентов) для тех, кому нужны } \\
\text { временнье деньги и дополнительный кредит } \\
\text { (без прочентов) 450-600 тьсс. иен на } 3 \text { месяца } \\
\text { для тех, кто меняет свою жизнь. В некото- } \\
\text { рых случаях ссуды прощаются }\end{array}$ & $\begin{array}{l}\text { Налоговые меры } \\
\text { Повышение отсрочки налогов для предприятий } \\
\text { при снижении выручки более чем на 20\%. } \\
\text { Уменьшение или освобождение от местного } \\
\text { налога на машинное оборудование и строитель- } \\
\text { ство для мальх и средних предприятий. } \\
\text { Обращение к арендодателям с просьбой рас- } \\
\text { смотреть возможность отсрочки оплаты аренды } \\
\text { и т.д. в зависимости от ситуации арендатора, } \\
\text { требующего от банков реструктуризации долга } \\
\text { арендодателя }\end{array}$ \\
\hline $\begin{array}{l}\text { Усиление помощи аренды для домохозяйств } \\
\text { с низкими доходами, чтобы помочь тем, кто } \\
\text { вот-вот потеряет свое жилье из-за снижения } \\
\text { доходов ниже прожиточного минимума. } \\
\text { Уменьшение или освобождение от взноса на } \\
\text { социальное обеспечение (здравоохранение, } \\
\text { страхование на случай длительного страхово- } \\
\text { го случая). } \\
\text { Отсрочка от коммунальных платежей (запрос) }\end{array}$ & \\
\hline \multicolumn{2}{|c|}{$\begin{array}{l}\text { Увеличение субсидии на отпуск (субсидия на корректировку занятости). } \\
\text { Объем субсидий вырос с апреля по июнь с 2/3 до 9/10 для малого и среднего бизнеса и с } 1 / 2 \text { до } \\
3 / 4 \text { для более крупных предприятий (при условии избегания увольнения). Охват расиирен за счет } \\
\text { непостоянных работников (менее } 20 \text { часов в неделю) }\end{array}$} \\
\hline
\end{tabular}

Источник: сост. по: [Cabinet Office of Japan 2020] 
На пути восстановления и предстоящие задачи

Безусловным приоритетом в борьбе с экономическими последствиями коронавируса является предотвращение распространения болезни. Для этого японское правительство планирует усилить систему обеспечения медицинской помощи, увеличив финансирование программы «грантов на комплексную экстренную поддержку» медицинским учреждениям для обеспечения коечного фонда. Также предполагается покрыть стоимость вакцинации желающих за счет государственных средств. Но параллельно был разработан комплекс мер для поддержания восстановления экономики.

Новый премьер-министр Японии, сменивший на этом посту Синдзо Абэ, намерен трансформировать структуру национальной экономики за счет развития секторов зеленой экономики и цифровизации. Правительством Японии поставлена цель сократить общие выбросы парниковых газов до нуля к 2050 г. Для достижения этой цели Япония создаст фонд в размере 2 трлн иен для обеспечения поддержки компаний на протяжении десяти лет, которые будут решать эту задачу и создавать соответствующие инновации.

Для реализации поставленных задач были созданы два фонда: первый фонд в размере 2 трлн иен (19 млрд долл. США) для поддержания исследований и разработок в зеленом секторе, сроком на десять лет; второй фонд в размере 10 трлн иен (95 млрд долл. США) для усиления развития исследовательской базы данных для «5 G» и других областей, связанных с цифровизацией. Продвижение цифровизации включает в себя инвестиции в размере более 1 трлн иен. Общие финансовые расходы, направленные в 2020 и 2021 гг. на восстановление экономики, составят 40 трлн иен, или 385 млрд долл. США.

Большое значение в восстановлении отводится укреплению позиций малого и среднего бизнеса. В частности, будет введена система субсидий до 100 млн иен на капитальные вложения и другие расходы, связанные с трансформацией бизнеса для повышения производительности. Также малому и среднему бизнесу будут доступны займы по низким процентным ставкам, выдаваемые государственными финансовыми учреждениями, такими как Банк развития Японии (Development Bank of Japan), Жилищное финансовое агентство Японии и др. (Japan Housing Finance Agency).

С июля по сентябрь 2020 г. японская экономика показала тенденцию к восстановлению (рис. 5). Однако третья волна коронавируса привела к усилению экономической неопределенности. Поэтому правительство подготовило «15-месячный бюджет», включающий третий пакет документов для закрепления своих экономических мер. Но подготовка бюджета имеет ряд сложностей, а именно - ухудшение финансового состояния государственных финансов. Объемы расходов за текущий финансовый год в Японии возросли до рекордного уровня - более 160 трлн иен (1540 млрд долл. США). Но дело 


\section{РОССИЯ И МИР В ХХІ ВЕКЕ}

в том, что основной доходной статьей выступают государственные облигации, на которые приходится $56 \%$ всех доходов бюджета ${ }^{2}$. Складывается парадоксальная ситуация, когда доходы обеспечиваются долгом, и для увеличения расходов на восстановление экономики правительство вынуждено выпускать дополнительные долговые обязательства.

Рост государственного долга в результате мер экономического стимулирования наблюдался практически во всех странах. В Японии он возрос до $42 \%$, в Германии - до $37 \%$, в США - до $15 \%$. Это создает риски для глобальной экономики. Япония находится в очень непростой финансовой ситуации и основная проблема, с которой она сталкивается, это обеспечение восстановления в условиях ограниченных финансовых ресурсов. Решение этой задачи также определит облик постпандемического восстановления страны.

\section{Закмючение}

Более низкий в сравнении с западными странами уровень заражений и смертей от Covid-19 в двух восточноазиатских странах - Южной Корее и Японии - обращает на себя внимание мирового сообщества. Весьма вероятно, что это связано с культурными факторами: отношением к соблюдению изданных государственными органами предписаний санитарно-гигиенического характера и, в частности, ношению масок [Tashiro, Shaw 2020]. Однако факт возникновения в этих странах второй и третьей волн пандемии, более сильных, чем первая, указывает на то, что правила не всегда функционируют идеально. Влияние генетических факторов на восприимчивость к вирусам еще более трудно доказуемо. Основной причиной пандемии является наличие вирусов как таковых, и ответные меры для борьбы с ними, как правило, недостаточны; все страны испытывают определенные сложности.

Критике можно подвергнуть ответные меры любого правительства, но нет прямого пути к борьбе с таким беспрецедентным феноменом, как пандемия Covid-19, поэтому в действиях государств всегда будет присутствовать элемент «спонтанности». И все же это не исключает возможности учиться на опыте других стран, чтобы, как минимум, избежать ненужных ошибок. В этом отношении опыт Южной Кореи и Японии может служить хорошим примером и способствовать выработке общих принципов борьбы с вирусными ситуациями. Внимания заслуживает общая подготовленность систем здравоохранения, высокая организация при изолировании очагов заражения.

2. Причина, почему японское правительство не обанкротилось, связана с особенностями структуры держателей облигаций: свыме 90\% облигаций принадлежит японским банкам и страховым компаниям, но маловероятно, что они начнут их продавать. 
Подходы корейского и японского правительств к преодолению экономических последствий Covid-19 объединяет ориентация на выполнение долгосрочных целей развития. Они укладываются в предложенный консалтинговой компанией McKinsey [McKinsey 2009] подход «три горизонта роста», используемый бизнесом. Данный подход схематично представляет управление развитием в определенный отрезок времени с параллельной максимизацией будущих возможностей для роста. Многие меры, предпринятые данными странами, устанавливают приоритет развития инновационных технологий как ответ на вызовы порожденные и усиленные пандемией.

Несмотря на то что, как показывает реальность, ситуация с коронавирусом может периодически ухудшаться, общий подход позволяет оперативно справляться с данными вспышками и адаптировать программы поддержки под ситуацию, не меняя главных целей развития. Поэтому основные моменты, отличающие Южную Корею и Японию от других стран, остаются актуальными. Постоянный мониторинг, кооперация общества и поддержка мер правительства по борьбе с эпидемией, в целом, будут определять подходы данных стран к борьбе с пандемией. В то же время восстановление будет управляемым, учитывающим меняющиеся условия среды - как экономической, так и геополитической.

\section{Библиография}

Белов А.В. Экономическая политика Японии в период пандемии // Мировая экономика и международные отношения. 2021. Т. 65. № 1. С. 33-41. https://doi.org/10.20542/0131-2227-202165-1-33-41

Белов А.В., Тихоцкая И.С. Первая волна пандемии COVID-19 в Японии: социальные и экономические аспекты // Азия и Африка сегодня. 2020. Вып. 10. С. 14-21.

Ершов М.В. Мир в 2020 году: новые проблемы обнажают системные изменения в экономике // Вопросы экономики. 2020. № 12. С. 5-23.

Федоровский A.H. Вызовы пандемии COVID-19 и приоритеты экономического развития Республики Корея // Контуры глобальных трансформаций: политика, экономика, право. 2020. T. 13. № 5. C. 204-218.

$4^{\text {th }}$ Emergency Support Package // MOEF. 2020. URL: https://www.moef.go.kr/nw/mosfnw/ detailInfograpView.do?searchNttId1=MOSF_000000000045329\&menuNo=4040500 (дата обращения: 14.12.2020).

Baker S.R., Bloom N., Davis S.J., Terry S.J. COVID-19 induced economic uncertainty // NBER Working Paper. 2020. N 26983. https://doi.org/10.3386/w26983

Bank of Korea. Официальный сайт Банка Кореи. URL: www.bok.or.kr

Brinca P., Duarte J.B., Faria e Castro M. Is the COVID-19 Pandemic a Supply or a Demand Shock? // Economic Synopses. 2020. N 31. URL: https://research.stlouisfed.org/publications/ economic-synopses/2020/05/20/is-the-covid-19-pandemic-a-supply-or-a-demand-shock

Building a coherent response for a sustainable post-COVID-19 recovery. Updated 13 July. 2020. URL: http://www.oecd.org/governance/pcsd/PRELIMINARY\%20VERSION_PCSD_PolicyResponse-Covid19_13\%20July\%202020.pdf 


\section{РОССИЯ И МИР В ХХІ ВЕКЕ}

CoronaBoard. Официальный портал информации о распространении Covid-19 в Кopee. URL: https://coronaboard.kr

Coronavirus (COVID-19): SME Policy Responses. Updated 15 July 2020. URL: https://read. oecd-ilibrary.org/view/?ref=119_119680-di6h3qgi4x\&title=Covid-19_SME_Policy_Responses

Covid-19 targeted emergency measures // SeoulU. 2020. URL: https://www.seoul.go.kr/ coronaV/coronaStatus.do?menu_code=18. (дата обращения: 2.12.2020).

Dighe, A., Cattarino, L., Cuomo-Dannenburg, G. et al. Response to COVID-19 in South Korea and implications for lifting stringent interventions // BMC Med. 2020. https://doi.org/10.1186/ s12916-020-01791-8

Emergency response plan for new coronavirus infections // Cabinet Office of Japan. 2020. URL: https://www.kantei.go.jp/jp/singi/novel_coronavirus/th_siryou/kinkyutaiou2_corona. pdf (in Japanese).

FitzRoy F., Spencer D. Economic Policy Response to the Pandemic: From COVID-19 Emergency to Economic Democracy // IZA Policy Paper. 2020. N 160. URL: http://ftp.iza.org/pp160.pdf

Ietto-Gillies G. Transnational corporations and international production: Concepts, theories and effects. Cheltenham: Edward Elgar Publishing, 2012.

Infectious Disease Control and Prevention Act // Korean Act N 14286. URL: https://elaw.klri. re.kr/eng_service/lawView.do?hseq=40184\&lang=ENG (дата обращения: 21.01.2021).

Johns Hopkins University. Covid-19 Data Repository by the Center for Systems Science and Engineering (CSSE), 2020. URL: https:/github.com/CSSEGISandData/COVID-19 (дата обращения: 20.01.2021).

Kim N. «More scary than coronavirus»: South Korea's health alerts expose private lives // The Guardian. 2020, 5 March. URL: https:/www.theguardian.com/world/2020/mar/06/more-scary-thancoronavirus-south-koreas-health-alerts-expose-private-lives

Kissinger H.A. The coronavirus pandemic will forever alter the world order // Wall Street Journal. 2020. Apr. 3. URL: https://www.wsj.com/articles/the-coronavirus-pandemic-will-forever-alterthe-world-order-11585953005

Kraaijenbrink J. Strategy Consulting (Elements in Business Strategy). Cambridge: Cambridge University Press. 2020. 75 p.

McKinsey. Enduring Ideas: The Three Horizons for Growth // McKinsey quarterly 1.12.2009 URL: https://www.mckinsey.com/business-functions/strategy-and-corporate-finance/our-insights/ enduring-ideas-the-three-horizons-of-growth (дата обращения: 19.01.2021).

National Institute of Population and Social Security Research (IPSS). Data on COVID-19 (2021). URL: www.ipss.go.jp/projects/j/Choju/covid19/index-en.asp. (дата обращения: 20.01.2021).

Nishiura H.T., Miyama A., Suzuki S., Jung K., Hayashi R., Kinoshita Y., Yang B., Yuan A,. Akhmetzhanov N. Linton Estimation of the asymptomatic ratio of novel coronavirus infections (COVID-19) // International Journal of Infectious Diseases. 2020. Vol. 94. P. 154-155.

Park S., Choi G.J., Ko H. Information technology-based tracing strategy in response to COVID-19 in South Korea-privacy controversies // Journal of the American Medical Association. 2020. Vol. 323. N 21. P. 2129-2130.

Porter M.E. Competitive Advantage, Agglomeration Economies, and Regional Policy // International Regional Science Review. 1996. Vol. 19. Issue 1-2. P. 85-90.

Professional Skills Development Schemes // Ministry of Employment and Labor (2020). URL: https://www.moel.go.kr/policy/policyinfo/reclamarion/list.do (дата обращения: 5.12.2020).

Regular briefing of central disaster and safety countermeasure headquarters on COVID-19 // Korea Centers for Disease Control and Prevention (2020). URL: http://ncov.mohw.go.kr/ tcmBoardView.do?brdId $=\&$ brdGubun $=\&$ dataGubun $=\&$ ncvContSeq $=353551 \&$ contSeq $=353551 \&$ board_id=140\&gubun=BDJ 
Shimizu K., Negita M. Lessons Learned from Japan's Response to the FirstWave of COVID-19: A Content Analysis // Healthcare. 2020. Vol. 8. N 4. P. 426.

Tashiro A., Shaw R. COVID-19 Pandemic Response in Japan: What Is Behind the Initial Flattening of the Curve? // Sustainability. 2020. Vol. 12. P. 5250.

Wolf M. What the World Can Learn from the Covid-19 Pandemic // Financial Times. 2020. Nov. 24

You J. Lessons from South Korea's Covid-19 Policy Response // The American Review of Public Administration, Volume. 2020. Vol. 50. N 6-7. P. 801-808. URL: https://doi.org/10.1177/ 0275074020943708

박시현. 정부, ‘한국판 뉴딜' 추진...3대 프로젝트 및 10대 중점과제 수립 [Правительство предлагает «Корейский Новый курс»...Три направления и 10 задач] // Denews. 2020. Мay 8. URL: http://www.denews.co.kr/news/articleView.html?idxno=13143 (дата обращения: 30.11.2020).

포스트 코로나 산업전략 '새판' 짠다...비대면·K-방역 육성 (Постокоронавирусный «Новый курс» и стратегия развития промышленности... Фокус на цифровизацию и медицину) // Government 24. 2020. Маy 6. URL: https://www.gov.kr/portal/ntnadmNews/2155404 (дата обращения: 30.11.2020).

\section{References}

$4^{\text {th }}$ Emergency Support Package. MOEF. 2020. URL: https://www.moef.go.kr/nw/mosfnw/ detailInfograpView.do?searchNttId1=MOSF_000000000045329\&menuNo=4040500 (дата обращения: 14.12.2020).

Baker S.R., Bloom N., Davis S.J., Terry S.J. COVID-19 induced economic uncertainty. NBER Working Paper. 2020. N 26983. https://doi.org/10.3386/w26983

Bank of Korea. Официальный сайт Банка Кореи. URL: www.bok.or.kr

Belov A. Ekonomicheskaia politika Iaponii v period pandemii [Economic Policy of Japan in the Time of Pandemic]. Mirovaya ekonomika i mezhdunarodnye otnosheniya [World economy and international relations]. 2021. Vol. 65. N 1. P. 33-41. (In Russ.)

Belov A., Tikhotskaya I. Pervaia volna pandemii COVID-19 v Iaponii: sotsial'nye i ekonomicheskie aspekty [The first wave of COVID-19 pandemic in Japan: social and economic considerations]. Aziia i Afrika segodnia [Asia and Africa Today]. 2020. Issue 10. P. 14-21. (In Russ.)

Brinca P., Duarte J.B., Faria e Castro M. Is the COVID-19 Pandemic a Supply or a Demand Shock? Economic Synopses. 2020. N 31. URL: https://research.stlouisfed.org/publications/economicsynopses/2020/05/20/is-the-covid-19-pandemic-a-supply-or-a-demand-shock

Building a coherent response for a sustainable post-COVID-19 recovery. Updated 13 July 2020. URL: http://www.oecd.org/governance/pcsd/PRELIMINARY\%20VERSION_PCSD_Policy-ResponseCovid19_13\%20July\%202020.pdf

CoronaBoard. Официальный портал информации о распространении Covid-19 в Кореe. URL: https://coronaboard.kr

Coronavirus (COVID-19): SME Policy Responses. Updated 15 July 2020. URL: https:// read.oecd-ilibrary.org/view/?ref=119_119680-di6h3qgi4x\&title=Covid-19_SME_Policy_Responses

Covid-19 targeted emergency measures. SeoulU. 2020. URL: https://www.seoul.go.kr/ coronaV/coronaStatus.do?menu_code=18 (дата обращения: 2.12.2020).

Dighe, A., Cattarino, L., Cuomo-Dannenburg, G. et al. Response to COVID-19 in South Korea and implications for lifting stringent interventions. BMC Med. 2020. https://doi.org/10.1186/s12916020-01791-8 


\section{РОССИЯ И МИР В ХХІ ВЕКЕ}

Emergency response plan for new coronavirus infections. Cabinet Office of Japan. 2020. URL: https://www.kantei.go.jp/jp/singi/novel_coronavirus/th_siryou/kinkyutaiou2_corona. pdf (in Japanese).

Ershov M.V. Mir v 2020 godu: novye problemy obnazhaiut sistemnye izmeneniia v ekonomike [The world in 2020: New challenges expose systemic changes in the economy]. Voprosy Ekonomiki [Economic issues]. 2020. N 12. P. 5-23. (In Russ.)

Fedorovsky A.N. Vyzovy pandemii COVID-19 i prioritety ekonomicheskogo razvitiia Respubliki Koreia [Challenge of COVID-19 and Priorities of Economic Development of the Republic of Korea]. Kontury global'nykh transformatsii: politika, ekonomika, pravo [Outlines of global transformations: politics, economics, law]. 2020. Vol. 13. N 5. P. 204-218. (In Russ.).

FitzRoy F., Spencer D. Economic Policy Response to the Pandemic: From COVID-19 Emergency to Economic Democracy. IZA Policy Paper. 2020. N 160. URL: http://ftp.iza.org/pp160.pdf

Ietto-Gillies, G. Transnational corporations and international production: Concepts, theories and effects. Cheltenham: Edward Elgar Publishing, 2012.

Infectious Disease Control and Prevention Act. Korean Act N 14286. URL https://elaw.klri. re.kr/eng_service/lawView.do?hseq=40184\&lang=ENG (date of access: 21.01 .2021 ).

Johns Hopkins University. Covid-19 Data Repository by the Center for Systems Science and Engineering (CSSE), 2020. URL: https://github.com/CSSEGISandData/COVID-19 (date of access: 20.01.2021).

Kim N. «More scary than coronavirus»: South Korea's health alerts expose private lives. The Guardian. 2020, March 5. URL: https://www.theguardian.com/world/2020/mar/06/more-scary-thancoronavirus-south-koreas-health-alerts-expose-private-lives

Kissinger H.A. The coronavirus pandemic will forever alter the world order. Wall Street Journal. 2020. April 3. URL: https://www.wsj.com/articles/the-coronavirus-pandemic-will-forever-alterthe-world-order-11585953005

Kraaijenbrink J. Strategy Consulting (Elements in Business Strategy). Cambridge: Cambridge University Press. 2020. 75 p.

McKinsey. Enduring Ideas: The Three Horizons for Growth. McKinsey quarterly 1.12.2009. URL: https://www.mckinsey.com/business-functions/strategy-and-corporate-finance/our-insights/ enduring-ideas-the-three-horizons-of-growth (date of access: 19.01.2021).

National Institute of Population and Social Security Research (IPSS). Data on COVID-19 (2021). URL: www.ipss.go.jp/projects/j/Choju/covid19/index-en.asp. (date of access: 20.01.2021).

Nishiura H., T. Miyama A., Suzuki S., Jung K., Hayashi R., Kinoshita Y., Yang B., Yuan A, Akhmetzhanov N. Linton Estimation of the asymptomatic ratio of novel coronavirus infections (COVID-19). International Journal of Infectious Diseases. 2020. Vol. 94. P. 154-155.

Park S., Choi G.J., Ko H. Information technology-based tracing strategy in response to COVID19 in South Korea-privacy controversies. Journal of the American Medical Association. 2020. Vol. 323. N 21. P. 2129-2130.

Porter M.E. Competitive Advantage, Agglomeration Economies, and Regional Policy. International Regional Science Review. 1996. Vol. 19. Issue 1-2. P. 85-90.

Professional Skills Development Schemes. Ministry of Employment and Labor (2020). URL: https://www.moel.go.kr/policy/policyinfo/reclamarion/list.do (date of access: 5.12.2020).

Regular briefing of central disaster and safety countermeasure headquarters on COVID-19. Korea Centers for Disease Control and Prevention (2020). URL: http://ncov.mohw.go.kr/tcmBoard View.do?brdId=\&brdGubun=\&dataGubun $=\&$ ncvContSeq=353551\&contSeq=353551\&board_id= 140\&gubun=BDJ

Shimizu K., Negita M. Lessons Learned from Japan's Response to the FirstWave of COVID-19: A Content Analysis. Healthcare. 2020. Vol. 8. N 4. P. 426. 
Tashiro A., Shaw R. COVID-19 Pandemic Response in Japan: What Is Behind the Initial Flattening of the Curve? Sustainability. 2020. Vol. 12. P. 5250.

Wolf M. What the World Can Learn from the Covid-19 Pandemic. Financial Times. 2020. Nov. 24.

You J. Lessons from South Korea's Covid-19 Policy Response. The American Review of Public Administration. 2020. Vol. 50. N 6-7. P. 801-808 https://doi.org/10.1177/0275074020943708

박시현. 정부, ‘한국판 뉴딜' 추진...3대 프로젝트 및 10대 중점과제 수립 [Government proposes «Korea-style New Deal»... 3 big projects and 10 tasks]. Denews. 2020. May 8. URL: http://www.denews.co.kr/news/articleView.html?idxno=13143 (date of access: 30.11.2020).

포스트 코로나 산업전략 '새판' 짠다...비대면·K-방역 육성 (Post-Corona Industrial 'New Deal'...Digitilazitaion and K-Pharma in focus). Government 24. 2020. May 6. URL: https://www. gov.kr/portal/ntnadmNews/2155404 (date of access: 30.11 .2020 ). 